\title{
Acute cardiac injury after subarachnoid haemorrhage: two case
}

\section{reports}

\author{
Marcello Marcì*1, Paolino Savatteri² ${ }^{2}$ Antonino Pizzuto², \\ Giuseppe Giammona ${ }^{2}$, Baldassare Renda ${ }^{2}$, Francesca Lojacono ${ }^{1}$ and \\ Nicola Sanfilippo ${ }^{1}$
}

\begin{abstract}
Address: ${ }^{1}$ Cardiology Department, Azienda Ospedaliera Villa Sofia, Palermo, Italy and ${ }^{2}$ Neurosurgery Department, Azienda Ospedaliera Villa Sofia, Palermo, Italy

Email: Marcello Marci* - marcellomarci@katamail.com; Paolino Savatteri - paolinosavat@hotmail.com;

Antonino Pizzuto - antoninopizzuto@libero.com; Giuseppe Giammona - giugiammona@tiscali.it; Baldassare Renda - baldorenda@libero.it; Francesca Lojacono - francilojacono@libero.com; Nicola Sanfilippo - nicsanfilippo@libero.com

* Corresponding author
\end{abstract}

Published: 9 December 2009

Cases Journal 2009, 2:9293 doi:10.1 186/1757-1626-2-9293

This article is available from: http://www.casesjournal.com/content/2/I/9293

(C) 2009 Marcì et al; licensee BioMed Central Ltd.

This is an Open Access article distributed under the terms of the Creative Commons Attribution License (http://creativecommons.org/licenses/by/2.0), which permits unrestricted use, distribution, and reproduction in any medium, provided the original work is properly cited.
Accepted: 9 December 2009
Received: 2 November 2009

\begin{abstract}
It is well known that cardiopulmonary complications are often associated to subarachnoid haemorrhage. For appropriate therapeutic managing it is very important to distinguish acute coronary syndrome from neurogenic myocardial injury, which is a reversible condition. Furthermore, because the hearts of brain dead patients may be utilized for therapeutic purpose, it has became of importance to rule out erroneous diagnosis of cardiac ischemia in order to avoid rejection of hearts potential suitable for transplantation.
\end{abstract}

We present a report of two female patients affected by cardiac complications caused by aneurismal subarachnoid haemorrhage admitted to our neurosurgical intensive care department.

\section{Case presentation \\ Case report I}

A 54-year-old Caucasian nun, with history of hypertension, treated with beta-blockers and ACE-inhibitors, was admitted to the neurosurgery department of our hospital for severe nuchal pain, vomit and reduced level of consciousness (Hunt -Hess grade IV). Brain CT scan revealed aneurysm of internal right carotid, in addition subarachnoid haemorrhage (SAH) was evidenced with extension into the III and IV ventricles.

ECG on admission showed normal sinus rhythm, without anomalies of ST-T tract, the corrected QT interval was 455 ms. Laboratory results demonstrated Troponin T level of
$3.75 \mathrm{ng} / \mathrm{ml}$ (normal value $<0.03 \mathrm{ng} / \mathrm{ml}$ ), creatinine kinase (CK) was $386 \mathrm{UI} / \mathrm{l}$ (normal value < $190 \mathrm{UI} / \mathrm{l}$ ), NT pro BNP (brain natriuretic peptide) peak level was 259.5 $\mathrm{pg} / \mathrm{ml}$ (normal value $<125 \mathrm{pg} / \mathrm{ml}$ ). The patient was sedated and intubated.

Transthoracic echocardiography documented wall motion abnormalities, namely akinesis of apex and distal interventricular septum, moreover ejection fraction was about $45 \%$. Inotropic agents, oxygen and Furosemide were administered. Clinical condition suddenly deteriorated after second haemorrhage, occurred soon before surgical correction of aneurysm. Since left ventricular wall motion anomalies persisted after declaration of cerebral 
death, the heart was considered not suitable for transplantation and only liver and kidneys could be successfully transplanted.

\section{Case report 2}

The second patient was a 71-year-old, Caucasian housewife, with no significant medical history, a part of arterial hypertension, she was not smoker nor diabetic. The patient presented with SAH (Hunt-Hess grade III-IV). First ECG demonstrated normal sinus rhythm, with a heart rate of $96 / \mathrm{m}$, and inverted $\mathrm{T}$ waves in $\mathrm{V} 1 \rightarrow \mathrm{V} 5$, the corrected QT interval was $518 \mathrm{~ms}$. After few hours it was observed the onset of paroxysmal atrial flutter that was successfully treated with Amiodarone (900 mg iv). Troponin T peak level was $0.469 \mathrm{ng} / \mathrm{ml}$, at admission $\mathrm{K}+$ was $3.4 \mathrm{mEq} / \mathrm{L}$, which after two days increased to $4.2 \mathrm{mEql} / \mathrm{L}, \mathrm{Na}+$ was 136 $\mathrm{mEq} / \mathrm{L}$, NTpro-BNP reached the peak level of $8166 \mathrm{pg} / \mathrm{ml}$. The echocardiogram demonstrated hypokinesis of distal septum and of apical region, moreover ejection fraction was $48 \%$. Clipping of the anterior left carotid was successfully performed. On the third postoperative day, wall motion abnormalities disappeared; the post-operative course was uneventful and the patient was discharged home after some weeks.

\section{Discussion}

In 1947 Byer et al firstly reported ECG changes in patients with cerebrovascular accidents [1]. Since then a conspicuous number of reports have called attention to cardiovascular abnormalities that frequently characterize the course of SAH $[2,3]$.

ECG changes seen in these patients may be divided in two categories: arrhythmias and repolarisation abnormalities.

Alteration of rhythm and conduction have been detected in about $4 \%$ of patients with SAH, the most common arrhythmias are sinus bradycardia and atrial fibrillation/ flutter (76\% of arrhythmias observed by Frontera et al) [46]. Potentially life threatening arrhythmias, such as torsades de pointes and ventricular tachycardia, are exceptional (about $0.4 \%$ ) and they are usually favoured by electrolytic imbalance and prolongation of QT interval $(4,5,6)$. Anomalies of repolarisation are observed in about $25-75 \%$ of patients with SAH, especially in the first three days after admission. Because the repolarisation changes are often similar to those seen in myocardial ischemia and infarction, the interest to this subject has increased to avoid erroneous diagnosis of acute coronary syndrome, that could interfere with a correct therapeutic management [7].

Moreover, approximately $40 \%$ of patients with SAH show a modest elevation of Troponin, CPK and CK-MB, although they do not rise to levels observed during acute myocardial infarction. Troponin elevation is correlated more to the degree of brain injury than to severity of cardiac dysfunction evidenced by echocardiography $[8,9]$.

Transient abnormalities of regional wall motion are detected by echocardiography in less than $5 \%$ of patients with minimal neurological deficit but in approximately half of patients with poor neurological grade $[11,12]$. Wall motion anomalies occur predominantly in postemenopausal women and in patients with severe neurological deficit and elevated levels of CK-MB and Troponin I. Specifically, features of echocardiographic abnormalities determined by SAH differ from those observed in myocardial ischemia for their inconsistence with ECGraphic changes $[11,12]$.

Among the proposed pathophysiologic mechanisms underlying ECG changes, ischemic heart disease was excluded by both autopsies and coronary angiographies.

The most plausible pathologic theory remains an autonomic dysregulation caused by a lesion of cortical, hypothalamic and mesencephalic centers controlling the autonomic nervous system [13-15].

As a matter of fact, an elevated concentration of catecholamines was observed in the hearts of animal models of intracranial haemorrhage $[14,15]$. Furthermore, catecholamine plasmatic levels are markedly elevated in patients with ECG changes than in patients without ECG variations $[14,15]$.

Post mortem examinations of patients who died of SAH demonstrated diffuse small and patchy subendocardial lesions, histologically appearing as myocardial contraction band necrosis [16]. Such myocytes necrosis is usually expression of hypercontracted state caused by cellular calcium overload due to toxic levels of catecholamine [17].

The clinical manifestations of SAH-induced cardiac dysfunction are similar to those observed in other conditions determined by massive release of catecholamine, such as tako-tsubo cardiomyopathy or transient left ventricular ballooning. As a matter of fact this syndrome, which predominates in post-menopausal women, is characterized by reversible wall motion abnormalities, slight elevation in myocardial markers, and transitory ST-T changes, in the absence of obstructive coronary artery disease. Although diagnostic criteria for tako-tsubo cardiomyopathy have initially excluded patients with intracranial bleeding, transient left ventricular apical ballooning could be a complication of SAH [18].

Cardiac involvement induced by SAH has several important clinical implications. 
Firstly association of ECG changes, elevations of serum markers of myocardial necrosis and left ventricular dysfunction, may mislead to an erroneous diagnosis of myocardial ischemia with delay in the diagnosis of SAH [17]. Since a rapid diagnosis is crucial for timely operation, and a correct diagnosis of intracranial bleeding can avoid inappropriate treatment with thrombolysis, aspirin or heparin [17], patients who present to emergency department with impairment of consciousness associated to electrocardiographic signs of acute myocardial ischemia, should undergo an urgent CT head scan to exclude intracranial bleeding. Although association between acute myocardial infarction and SAH is very rare [19], coronary arteriography may be necessary when a simultaneous acute coronary syndrome is suspected, especially in male patients with low grade neurologic deficit and extremely elevated and persistent Troponin levels. Although cardiac dysfunction caused by SAH is usually reversible, it may onset dramatically with pulmonary oedema, and it might be indicative of a poor outcome.

Last but not least, patients affected by SAH are generally relatively young and healthy patients, that represent potential numerous organ donors $[17,20]$.

There may be the risk of considering the hearts of irreversibly comatose patients not to be fit for a transplant because they often reveal mild-to-severe left ventricular wall motion abnormalities that, as demonstrated by several studies [20], are generally reversible. For this reason Deibert and co-workers recommend a re-evaluation of heart after brain death declaration when a left ventricular dysfunction has been detected soon after diagnosis of $\mathrm{SAH}$, in order to avoid an inappropriate rejection of donor. Since criteria for selecting a donor hearts are not standardized, several parameters, such as Troponin, BNP and catecholamine concentrations as well as echocardiographic features, should be cautiously considered when evaluating a brain-dead donor.

\section{Abbreviations}

CT: computed tomography; ECG: electrocardiogram; SAH: subarachnoid haemorrhage.

\section{Consent}

Written informed consents were obtained from the second patient and from the first patient's relatives for publication of this case report, a copy of the written consents is available for review by the Editor-in-chief of this journal.

\section{Competing interests}

The authors declare that they have no competing interests.

\section{Authors' contributions}

$\mathrm{MM}, \mathrm{FL}, \mathrm{NS}$ analyzed and interpreted patient's ECG and echocardiograms. MM was a major contributor in writing the manuscript. BR, AP, PS, GG contributed to acquisition of data, analyzed the patient data regarding the neurological disease and the intensive care. All Authors read and approved the final manuscript.

\section{References}

I. Byer E, Ashman R, Toth LA: Electrocardiogram with large upright $\mathbf{T}$ wave and long Q-T intervals. Am Heart J 1947, 33:796-801.

2. Beard EF, Robertson JW, Robertson RCL: Spontaneous subarachnoid haemorrhage simulating acute myocardial infarction. Am Heart J 1959, 58:755-759.

3. Lanzino G, Kongable GL, Kassell NF: Electrocardiographic abnormalities after non traumatic subarachnoid haemorrhage. J Neurosurg Anesthesiol 1994, 6:156-162.

4. Frontera JA, Parra A, Shimbo D, Fernandez A, Schmidt JM, Peter P, Claassen J, Wartenberg KE, Rincon F, Badjata N, Naidech A, Connolly ES, Mayer SA: Cardiac arrhythmias after subarachnoid hemorrhage: risk factors and impact on outcome. Cerebrovasc Dis 2008, 26(I):71-78.

5. Andreoli A, Di Pasquale G, Pinelli G, Grazi P, Tognetti F, Testa C: Subarachnoid haemorrhage: frequency and severity of cardiac arrhythmias. A survey of 70 cases studied in the acute phase. Stroke 1987, I 8:558-564.

6. Di Pasquale G, Pinelli G, Andreoli A, Manini GL, Grazi P, Tognetti F: Torsade de pointes and ventricular flutter-fibrillation following spontaneous cerebral subarachnoid hemorrhage. Int J Cardiol 1988, I8(2): 163-I72.

7. Cropp CF, Manning GW: Electrocardiographic change simulating myocardial ischaemia and infarction associated with spontaneous intracranial haemorrhage. Circulation 1960, 22:25-38.

8. Bulsara KR, Mc Girt MJ, Liao L, Villavicencio AT, Borel C, Alexander $\mathrm{MJ}$, Friedman $\mathrm{AH}$ : Use of the peak Troponin value to differentiate myocardial infarction from reversible neurogenic left ventricular dysfunction associated with aneurysmal subarachnoid haemorrhage. J Neurosurg 2003, 98:524-528.

9. Parekh N, Venkatesh B, Cross D, Leditschke A, Atherton J, Miles W, Winning A, Clauge A, Rickard C: Cardiac Troponin I predicts myocardial dysfunction in aneurismal subarachnoid hemorrhage. J Am Coll Cardiol 2000, 36: I 328-I 335.

10. Mayer SA, Lin J, Homma S, Solomon RA, Lennihan L, Sherman D, Fink ME, Beckford A, Klebanoff LM: Myocardial injury and left ventricular performance after subarachnoid hemorrhage. Stroke 1999, 30:780-786.

II. Kothavale A, Banki NM, Kopelnik A, Yarlagadda S, Lawton MT, Ko N, Smith WS, Drew B, Foster E, Zaroff JG: Predictors of left ventricular regional wall motion abnormalities after subarachnoid haemorrhage. Neurocrit Care 2006, 4(3): 197-198.

12. Zarof JG, Rodorf GA, Ogilvy CS, Picard MH: Regional patterns of left ventricular systolic dysfunction after subarachnoid haemorrhage: evidence of neurally mediated cardiac injury. Jam Soc Echocardiogr 2000, I 3:774-779.

13. Banki NM, Kopelni A, Dae MW, Miss J, Tung P, Lawton MT, Drew BJ, Foster E, Smith W, Parmley WW, Zaroff JG: Acute neurocardiogenic injury after subarachnoid hemorrhage. Circulation 2005, I | 2:3314-3319.

14. Cruickshank JM, Neil-Dwyer G, Stott AW: Possible role of catecholamines, corticosteroids and potassium in the production of electrocardiographic abnormalities associated with subarachnoid hemorrhage. $\mathrm{Br}$ Med J 1974, 36:697-706.

15. Lee VH, Oh JK, Mulvagh SL, Wijdicks EFM: Mechanisms in neurogenic stress cardiomyopathy after aneurysmal subarachnoid hemorrhage. Neurocritical Care 2006, 05:243-249.

16. Baroldi G: Pathologic evidence of myocardial damage following acute brain injuries. In Heart-brain interactions Ist edition. Edited by: Di Pasquale G, Pinelli G. Berlin:Springer-Verlag; 1992:43-47. 
17. Morello A, Marcì M: La sindrome cuore-cervello. Pseudoinfarti miocardici in corso di emorragia subaracnoidea. GIMUPS 2005, 7(3): 14-23.

18. Lee VH, Connolly HM, Fulgham JR, Manno EM, Brown RD Jr, Wijdicks EF: Tako-tsubo cardiomyopathy in aneurysmal subarachnoid hemorrhage: an underappreciated ventricular dysfunction. J Neurosurg 2006, 105:264-270.

19. Velden LBJ van der, Otterspoor LC, Schultze Kool LJ, Biessels GJ, Verheugt FWA: Acute myocardial infarction complicating subarachnoid haemorrhage. Neth Heart J 2009, 17:284-287.

20. Deibert E, Aiyagari $V$, Diringer MN: Reversible left ventricular dysfunction associated with raised Troponin I after subarachnoid haemorrhage does not preclude successful heart transplantation. Heart 2000, 84:205-207.

Publish with Bio Med Central and every scientist can read your work free of charge

"BioMed Central will be the most significant development for disseminating the results of biomedical research in our lifetime. "

Sir Paul Nurse, Cancer Research UK

Your research papers will be:

- available free of charge to the entire biomedical community

- peer reviewed and published immediately upon acceptance

- cited in PubMed and archived on PubMed Central

- yours - you keep the copyright

Submit your manuscript here:

http://www.biomedcentral.com/info/publishing_adv.asp 